\title{
Appendiceal Carcinoma Pathologic Regional Lymph Nodes TNM Finding v8
}

National Cancer Institute

\section{Source}

National Cancer Institute. Appendiceal Carcinoma Pathologic Regional Lymph Nodes

TNM Finding v8. NCI Thesaurus. Code C134103.

A pathologic finding about one or more characteristics of appendiceal carcinoma,

following the rules of the TNM AJCC v8 classification system as they pertain to staging of regional lymph nodes. 